\title{
Evidence of long-distance coastal sea migration of Atlantic salmon, Salmo salar, smolts from northwest England (River Derwent)
}

\author{
Amy Green ${ }^{1 *} \mathbb{D}$, Hannele M. Honkanen ${ }^{1}$, Philip Ramsden², Brian Shields², Diego del Villar-Guerra³, \\ Melanie Fletcher ${ }^{4}$, Silas Walton ${ }^{4}$, Richard Kennedy ${ }^{5}$, Robert Rosell ${ }^{5}$, Niall O'Maoiléidigh ${ }^{6}$, James Barry ${ }^{7}$, \\ William Roche ${ }^{7}$, Fred Whoriskey ${ }^{8}$, Peter Klimley ${ }^{9}$ and Colin E. Adams ${ }^{1}$
}

\begin{abstract}
Background: Combining data from multiple acoustic telemetry studies has revealed that west coast England Atlantic salmon (Salmo salar L.) smolts used a northward migration pathway through the Irish Sea to reach their feeding grounds. Hundred Atlantic salmon smolts were captured and tagged in May 2020 in the River Derwent, northwest England as part of an Environment Agency/Natural England funded project.

Results: Three tagged smolts were detected on marine acoustic receivers distributed across two separate arrays from different projects in the Irish Sea. One fish had migrated approximately $262 \mathrm{~km}$ in 10 days from the river mouth at Workington Harbour, Cumbria to the northernmost receiver array operated by the SeaMonitor project; this is the longest tracked marine migration of an Atlantic salmon smolt migrating from the United Kingdom. This migrating fish displayed behaviours which resulted in fast northward migration. The remaining two fish were detected on a receiver array operated by a third project: the Collaborative Oceanography and Monitoring for Protected Areas and Species (COMPASS).

Conclusion: These detections further provide evidence that migration to reach marine feeding grounds of at least a proportion of salmon smolts from rivers draining into the Irish Sea is northerly, though without a southern marine array it is impossible to conclude that this is the only route. The pattern of these detections would not have been possible without the collaborative efforts of three distinct and separately funded projects to share data. Further work is required to fully understand migration trajectories in this species on the west coast of the British Isles.
\end{abstract}

Keywords: Salmo salar, Smolt, Acoustic telemetry, Migration, Irish Sea

\section{Background}

For diadromous fish species, that migrate between marine and freshwater habitats, there is commonly very considerable disparity in knowledge about their ecology in different habitats [1, 2]. For the anadromous Atlantic salmon (Salmo salar) there is a relatively good

*Correspondence: 2508110G@student.gla.ac.uk

${ }^{1}$ Scottish Centre for Ecology and the Natural Environment, Glasgow G63 OAW, UK

Full list of author information is available at the end of the article understanding of the ecology of the freshwater phase of the life cycle in published literature; this is in marked contrast to that of the marine phase (post-smolt) [3-5]. In particular, we have only a limited comprehension of their marine habitat use and the migration pathways they use to migrate between their natal river and their marine foraging areas in both directions [6]. The limited knowledge gathered for Atlantic salmon making their outwards marine migrations and the environments through which they migrate comes principally from two approaches: the capture of salmon at sea from either targeted [7-9] original author(s) and the source, provide a link to the Creative Commons licence, and indicate if changes were made. The images or other third party material in this article are included in the article's Creative Commons licence, unless indicated otherwise in a credit line to the material. If material is not included in the article's Creative Commons licence and your intended use is not permitted by statutory regulation or exceeds the permitted use, you will need to obtain permission directly from the copyright holder. To view a copy of this licence, visit http://creativecommons.org/licenses/by/4.0/. The Creative Commons Public Domain Dedication waiver (http://creativeco mmons.org/publicdomain/zero/1.0/) applies to the data made available in this article, unless otherwise stated in a credit line to the data. 
or opportunistic [3] capture by fisheries vessels and from telemetry studies tracking fish tagged in freshwater to marine habitats [4, 10-16].

The former study approach can provide important, spatially explicit, but point source data on the presence of migrating salmon [17-19]. This approach has shown us that salmon emanating from rivers in southern Europe migrate north to marine feeding grounds in the Norwegian Sea and/or to the north-west Atlantic, to the seas off west Greenland [1,3,20]. Using this approach however, it is difficult to reconstruct migration pathways and passage speeds, in part because it requires fish collection over an enormous spatial area from which pathways need to be inferred.

The telemetry approach applied to seaward migrating smolts has until now, mostly centred around tracking using acoustic technology. Acoustic telemetry studies, typically using fixed position, continuous monitoring acoustic receivers and fish tagged with acoustic transmitters, have rapidly become a common method to investigate fish migration patterns (large and small), site fidelity and diel and seasonal movements [17-19] through both freshwater and marine environments. This technique has the advantage that it can provide highly precise spatial information and thus more precise migration pathways. The disadvantage, when this approach is used to track anadromous species migrating into marine systems, is that the financial and logistical costs of maintaining suitably positioned receivers increases exponentially with distance from the river from which individuals are being tracked. Collaboration amongst global and regional projects, often with differing primary aims, allow for fish migration information in the spatially extensive marine environments to be obtained in a more cost-effective way $[21,22]$.

In one of the few studies to have looked at migration pathways of anadromous Atlantic salmon in the Irish Sea using acoustic telemetry, Barry and colleagues [4] analysed fish migrating from Castletown River and the River Boyne, both of which discharge into the west of the Irish Sea (on the east of Ireland). They found three Atlantic salmon smolts tagged in these tributaries were detected in the north Irish Sea, suggesting a northern trajectory after leaving the river mouth, taking them towards the North Channel, giving them access to the North Atlantic. Of these, one fish was detected on one of only two marine receivers, $250 \mathrm{~km}$ to the north, approximately 30 days after leaving its natal river. This finding provided the first evidence of a northerly marine migration trajectory for Atlantic salmon migrating into the Irish Sea. However, because there was no southern marine receiver array, it was not possible to completely exclude the possibility of some southern migration occurring [4].
Here we provide a Telemetry Case Report on sea migrating Atlantic salmon from a river in north-west England discharging into the eastern Irish Sea. We show that Atlantic salmon smolts once entering the Irish Sea took a northern pathway suggesting a northern trajectory towards the North Channel, giving them access to the more open North Atlantic. We extend the maximum distance that a post-smolt Atlantic salmon has been tracked in acoustic studies in Europe to date. This study also demonstrates the need for both collaboration and data sharing between telemetry projects with alternative funding sources and project aims and for cross project detection compatibility to obtain maximum benefit from highly expensive, logistically demanding marine telemetry studies.

\section{Methods}

The River Derwent, Cumbria, North-West England, (catchment: $679 \mathrm{~km}^{2}$ ) supports a population of wild Atlantic salmon. As part of a multi-partner project, led by the University of Glasgow, 100 Atlantic salmon smolts were captured in May 2020 by rotary screw trap and fyke net in St. Johns Beck, Threkheld (54.61058, - $\left.3.06168^{\circ}\right)$, a tributary in the River Derwent which flows through Bassenthwaite Lake, before draining west into the outer Solway Firth at the Port of Workington $\left(54.649487^{\circ},-3.568865^{\circ}\right) 50 \mathrm{~km}$ from the trapping site. The smolts were tagged at the capture location under licence (UK Home Office PPL 70/8794) with V7-2L $(69 \mathrm{kHz})$ coded acoustic transmitters (VEMCO Ltd., $7 \mathrm{~mm}$ diameter, $1.7 \mathrm{~g}$ in air, average transmission delay of $45 \mathrm{~s}$ ) and released during daylight hours. Acoustic receivers [VR2W and VR2Txs (Vemco Ltd.)] were deployed throughout the Derwent system $(n=29)$ from the tagging site to where the river discharges to the open sea (see Fig. 1). Two marine arrays were deployed. One, part of the Collaborative Oceanography and Monitoring for Protected Areas and Species (COMPASS) project, in the Irish Sea, comprised 22 Vemco VR2ARs receivers, deployed as a curtain over $24 \mathrm{~km}$ from Northern Ireland $\left(54.8885002^{\circ},-5.6567001^{\circ}\right)$ to Scotland $\left(54.9700012^{\circ}\right.$, $\left.-5.3150501^{\circ}\right)$. The other, deployed by a different project, the SeaMonitor project, comprised of six Vemco VR2ARs, deployed as a curtain over a distance of $2 \mathrm{~km}$ from $55.340280^{\circ},-6.568360^{\circ}$ to $55.349130^{\circ},-6.545230^{\circ}$ (see Fig. 2).

\section{Results}

In total, 100 Atlantic salmon smolts were captured using in the upper reaches of the River Derwent, northwest England. The mean $( \pm \mathrm{SD})$ fork length and mass of tagged salmon smolts was $139.36 \pm 0.65 \mathrm{~mm}$ and $27.89 \pm 0.42 \mathrm{~g}$ (range: 157-130 $\mathrm{mm}, 21.4-41.4 \mathrm{~g}$ ) respectively. The 


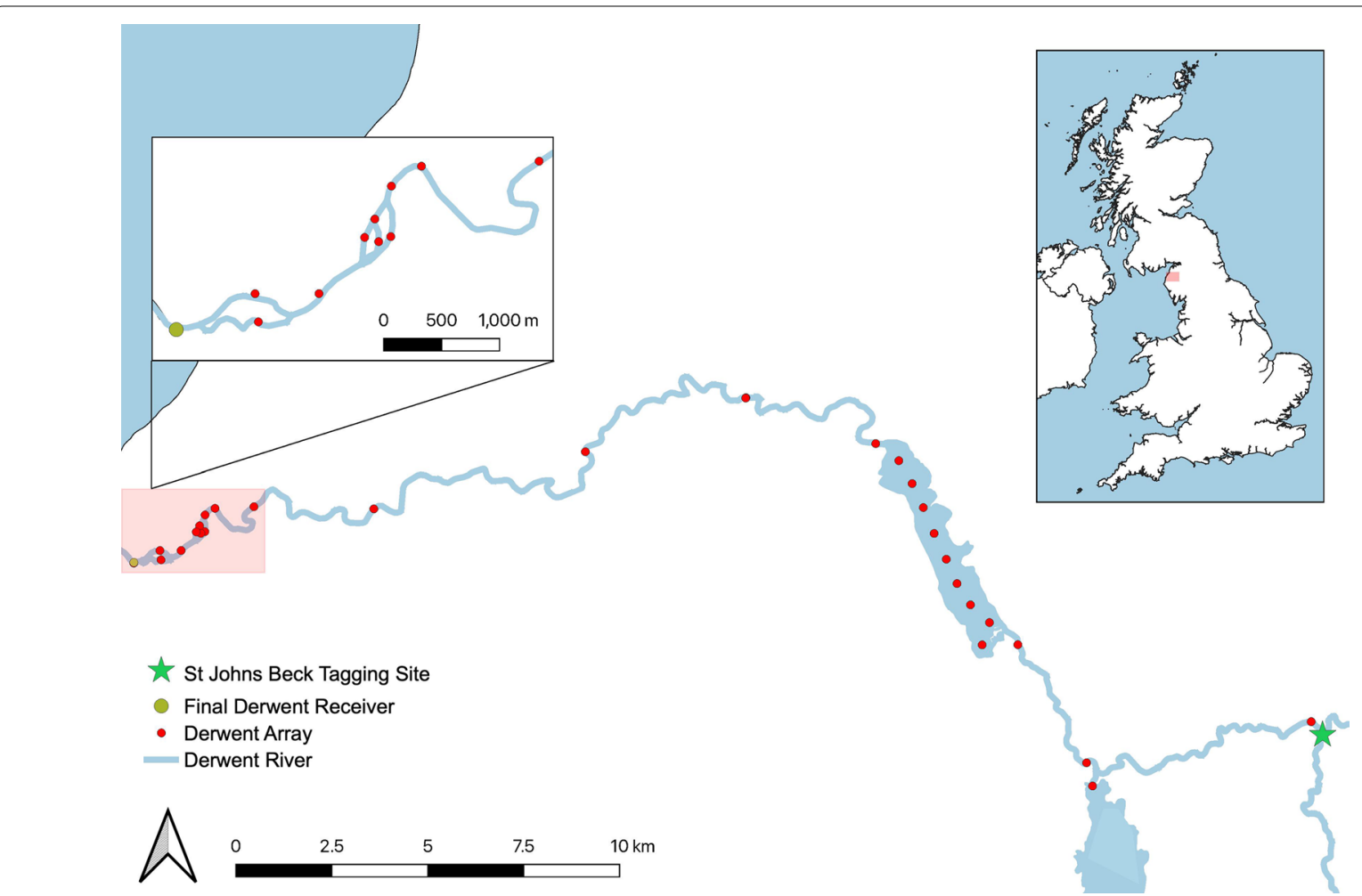

Fig. 1 Map showing the River Derwent Tracking Project receiver locations and the trapping and tagging site at St. Johns Beck

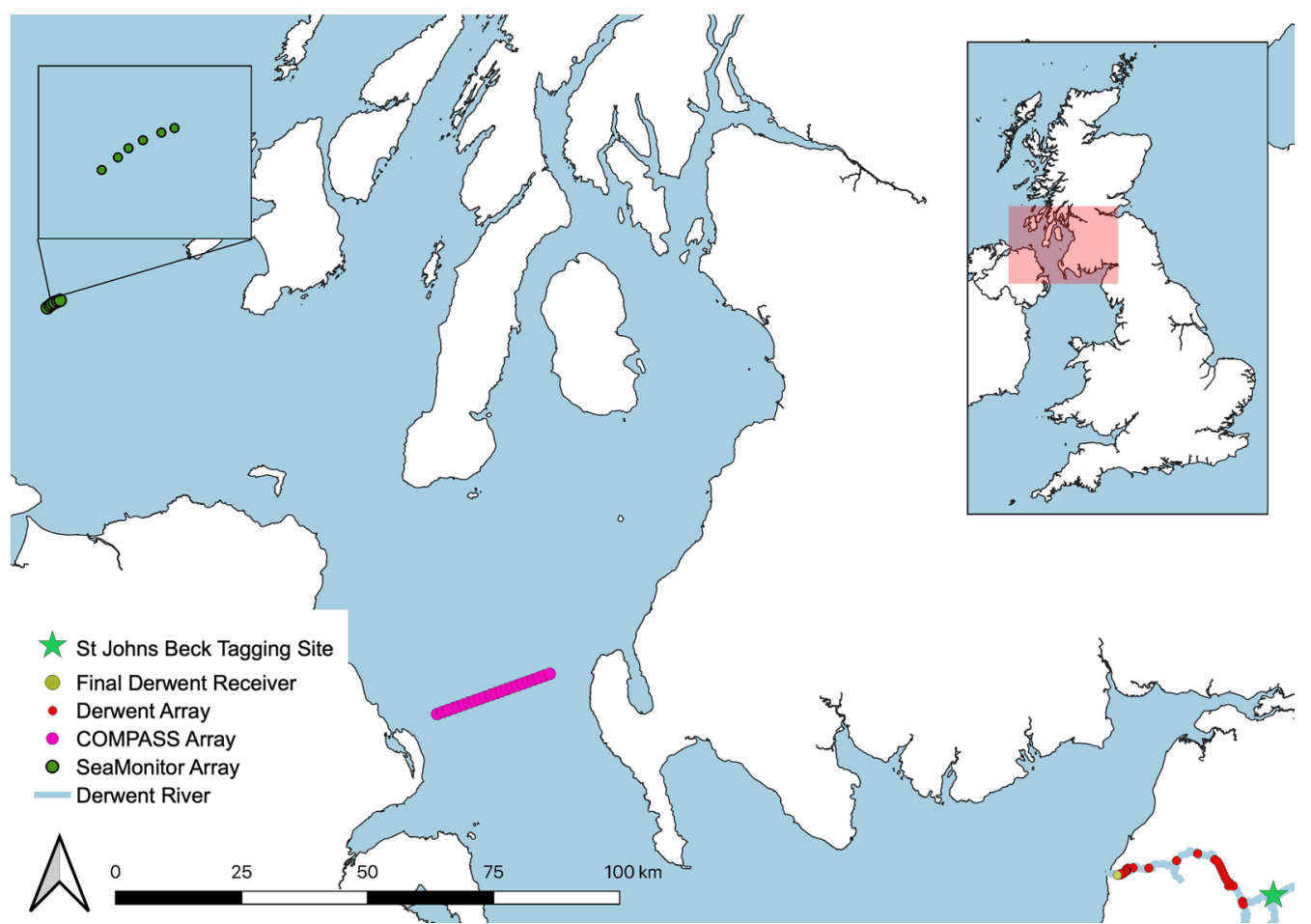

Fig. 2 The two marine curtain receiver arrays from the two distinct projects (COMPASS and SeaMonitor) alongside the smolt tagging site and Derwent system, Cumbria 
mean ( \pm SD) tag burden was $5.1 \pm 0.07 \%$ (range: $3.5-$ $6.7 \%$ ). Eight smolts (8\% of those tagged) were detected at the last River Derwent receiver at the river mouth before Workington port (see Fig. 1), equating to a river loss rate of $1.84 \% / \mathrm{km}$. The mean migration speed of the eight successful migrants from the release site to the final receiver before sea entry was $0.4 \mathrm{~km} \mathrm{day}^{-1}$. The eight successful fish had a mean $( \pm \mathrm{SD})$ fork length and mass of $141.38 \pm 5.10 \mathrm{~mm}$ and $28.84 \pm 3.11 \mathrm{~g}$ compared to the unsuccessful salmon smolts $(n=92) 139 \pm 6.33 \mathrm{~mm}$ and $27.48 \pm 4.11 \mathrm{~g}$, respectively.

Thirty seven point five percent of the salmon smolts that entered the marine environment were detected on receivers deployed across the Irish Sea. Two smolts $(34,946$ and 34,988$)$ were detected on the COMPASS array and another smolt $(34,920)$ was detected on the SeaMonitor array. Unfortunately, the distances between receivers $(\mathrm{ca} .1 \mathrm{~km})$ exceed the presumptive detection ranges $(\mathrm{ca} .400 \mathrm{~m})$ [23] for both marine arrays, therefore, it is plausible that more smolts may have passed both arrays undetected.

Tag 34946 was last detected entering Workington harbour from the river on 18th May 2020 at 16:34 pm (UTC) and subsequently detected at both marine arrays. After approximately 6 days at sea, travelling a distance of approximately $138 \mathrm{~km}$, this fish was detected on the
COMPASS array $\left(54.9544983^{\circ},-5.3801298^{\circ}\right)$ on 31 st May 2020 at 1:38 am. This equates to a movement speed of $23 \mathrm{~km} \mathrm{day}{ }^{-1}$ or 1.72 body lengths per second (BL/s). Seven detections were made of this fish at this site, providing confidence that this was not a false detection. This fish left this receiver location on 31st May 2020 at 1:46 am and travelled in a westerly direction to be redetected again on the COMPASS array $\left(54.9429016^{\circ}\right.$, - 5.4289398 $)$ on 31st May 2020 at 4:29 am, after travelling a further $3.37 \mathrm{~km}$ at $2.41 \mathrm{BL} / \mathrm{s}\left(29.77 \mathrm{~km} \mathrm{day}^{-1}\right)$. There was only one detection on this receiver at this site (Fig. 3, Table 1). Tag 34988 was last detected at Workington on 24th May 2020 at 15:58 pm. After approximately 9 days at sea, travelling a minimum distance of $137.8 \mathrm{~km}$, this smolt was detected on the COMPASS array $\left(54.9389992^{\circ},-5.44521^{\circ}\right)$ on the 3rd June 2020 at $12: 49 \mathrm{pm}$, having travelled at a speed of $15.3 \mathrm{~km} \mathrm{day}^{-1}$ or $1.08 \mathrm{BL} / \mathrm{s}$. Tag 34988 was detected six times on this receiver (Fig. 4 , Table 1 ).

Tag 34920 was last detected entering the marine environment on the 18th May 2020 at 16:34 pm. Taking 10 days to travel at sea, this smolt covered a distance of $262 \mathrm{~km}\left(26.2 \mathrm{~km} \mathrm{day}^{-1}\right)$ at a speed of $1.97 \mathrm{BL} / \mathrm{s}$. This smolt was the only smolt from the River Derwent tracking project to be detected only on the SeaMonitor array $\left(55.567250^{\circ},-6.947361^{\circ}\right)$. This smolt must have passed

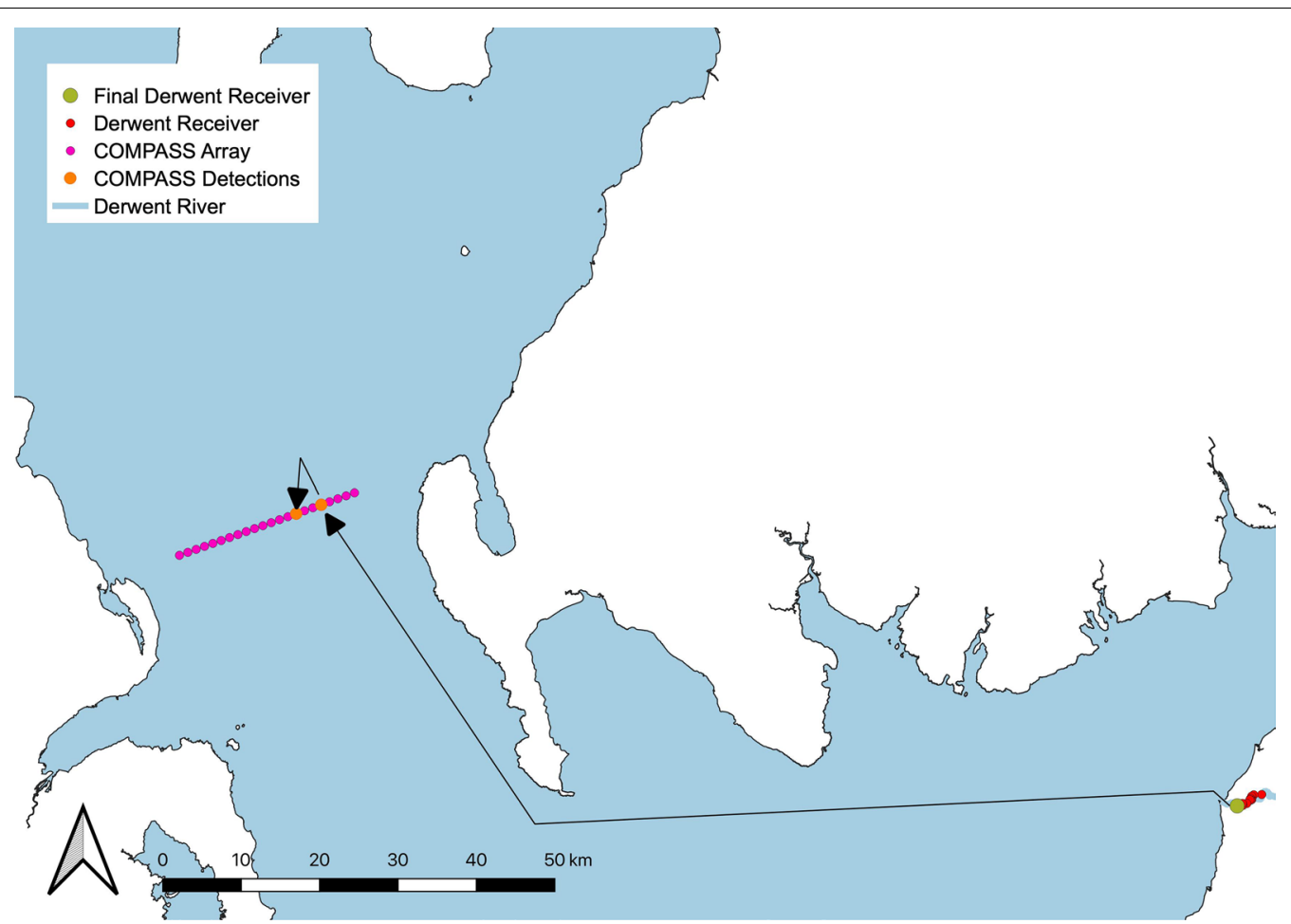

Fig. 3 Minimum theoretical distance travelled by fish 34,946, successfully migrating from the River Derwent's last river receiver to the COMPASS array in the Irish Sea 


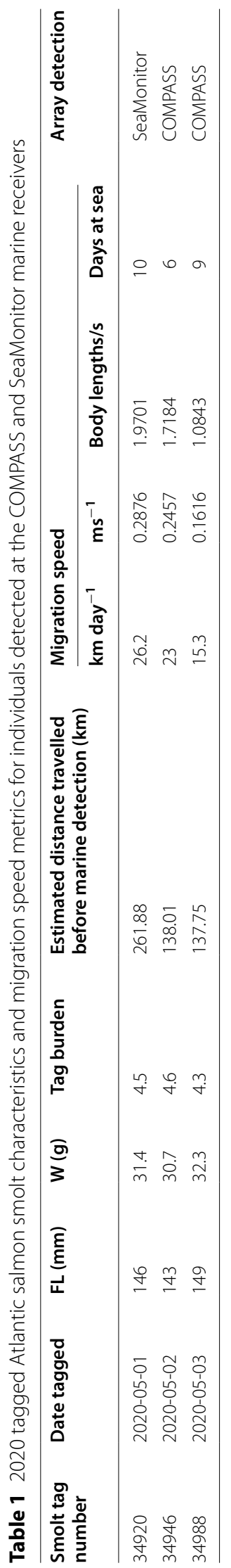




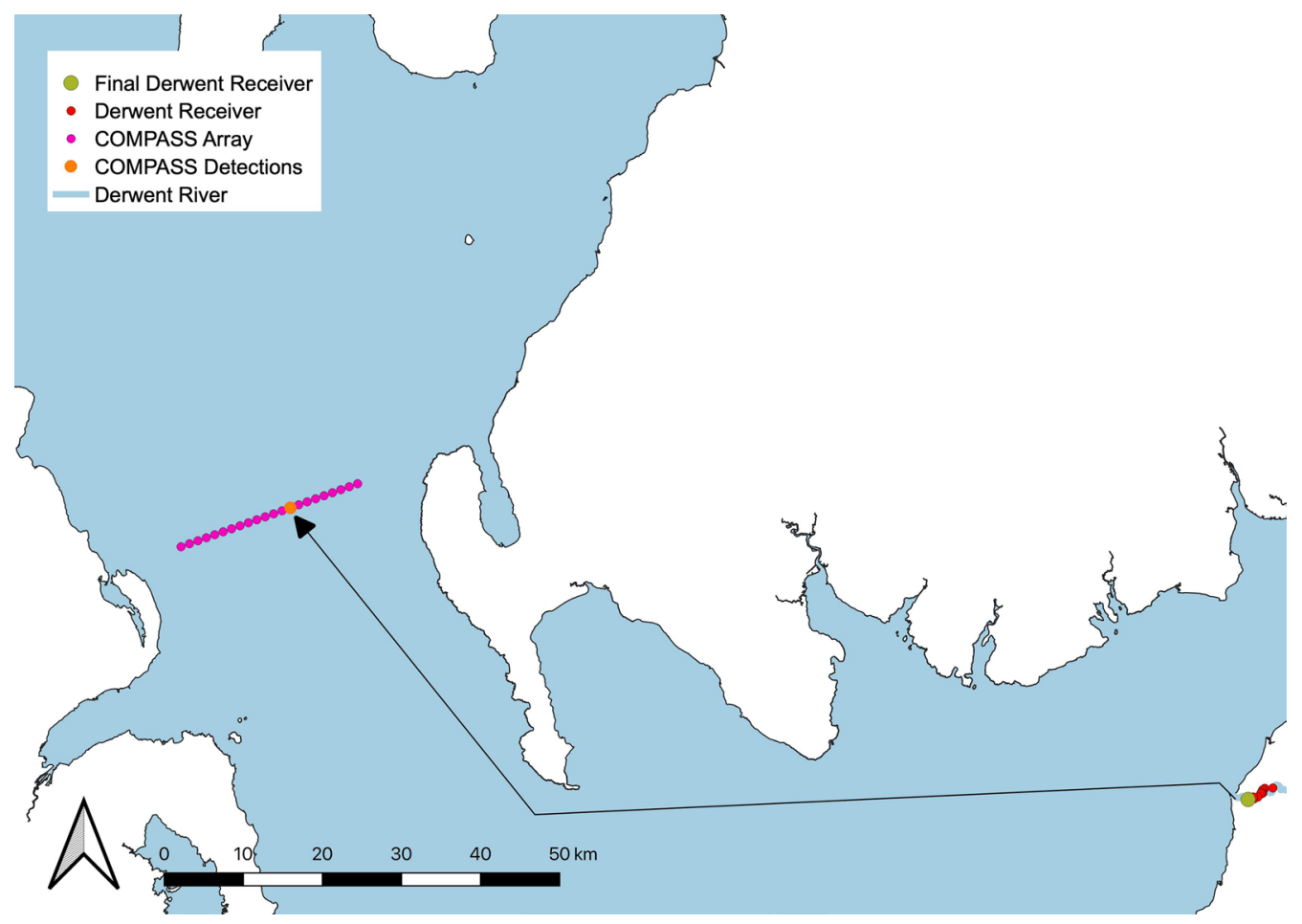

Fig. 4 Minimum theoretical distance travelled by fish 34,988, successfully migrating from the River Derwent's last river receiver to the COMPASS array in the Irish Sea

the area of the COMPASS array without being detected. This fish was detected twice on the SeaMonitor array (Fig. 5, Table 1).

The overall net movement of all three River Derwent salmon smolts was northwards as registered in the marine receiver arrays. Thus, fish effectively must have taken an initially westly trajectory towards the Irish coast once they left the riverine environment, followed by a northerly trajectory towards the North Channel (Figs. 3, 4,5 , Table 1). Without a southern receiver array, we cannot completely exclude the possibility of southern migration occurring initially for these fish or others that were not detected.

\section{Discussion}

The results presented here provide consistent evidence of northerly movements by smolts after entering the marine environment of the Irish Sea. Despite a small sample size, the three individuals detected had relatively similar migration speeds over varying distances. The average speed recorded for all three salmon smolts $\left(0.23 \mathrm{~ms}^{-1}\right.$ or $21.5 \mathrm{~km} \mathrm{day}^{-1}$ ) is similar to the findings of Chaput et al. [15] of $17-22 \mathrm{~km} \mathrm{day}^{-1}$ during Atlantic salmon smolt migration in the Gulf of St. Lawrence (North America). However, the travel speeds found in the study reported here are considerably higher than those reported in the
Barry et al. [4] study, which indicated migration speeds of ca.7 km day ${ }^{-1}$. In their study, Barry et al. [4] tagged smolts in two rivers in Ireland, Castletown River (54.026 $\left.-6.429^{\circ}\right)$ and the River Boyne $\left(53.721^{\circ},-6.427^{\circ}\right)$, which is at the same latitude as the River Derwent. The three river systems which all flow into the Irish Sea are separated by a channel of ca. $200 \mathrm{~km}$, although the channel narrows to ca. $35 \mathrm{~km}$ further north creating a substantially narrower route for migration to the north. Due to a gradually narrowing channel, individuals are more likely to migrate through similar marine habitats and theoretically should experience similar environmental conditions. One explanation for the difference in the travel speeds noted above, is that migration progression rates are influenced by a combination of regional environmental differences and population specific features.

The Irish Sea is a semi-enclosed body of water characterised by concurrent action tides entering from both the north and the south $[24,25]$, creating semi-diurnal tides with areas of both high and low energy mixing [26]. However, intra-annual variability has been found there and it is known that current direction can change under specific environmental conditions such as wind, causing a greater southerly water flow [4, 24]. SALSEA-Merge [7] showed that post-smolt salmon use such currents during migration in marine environments and based on captures of 


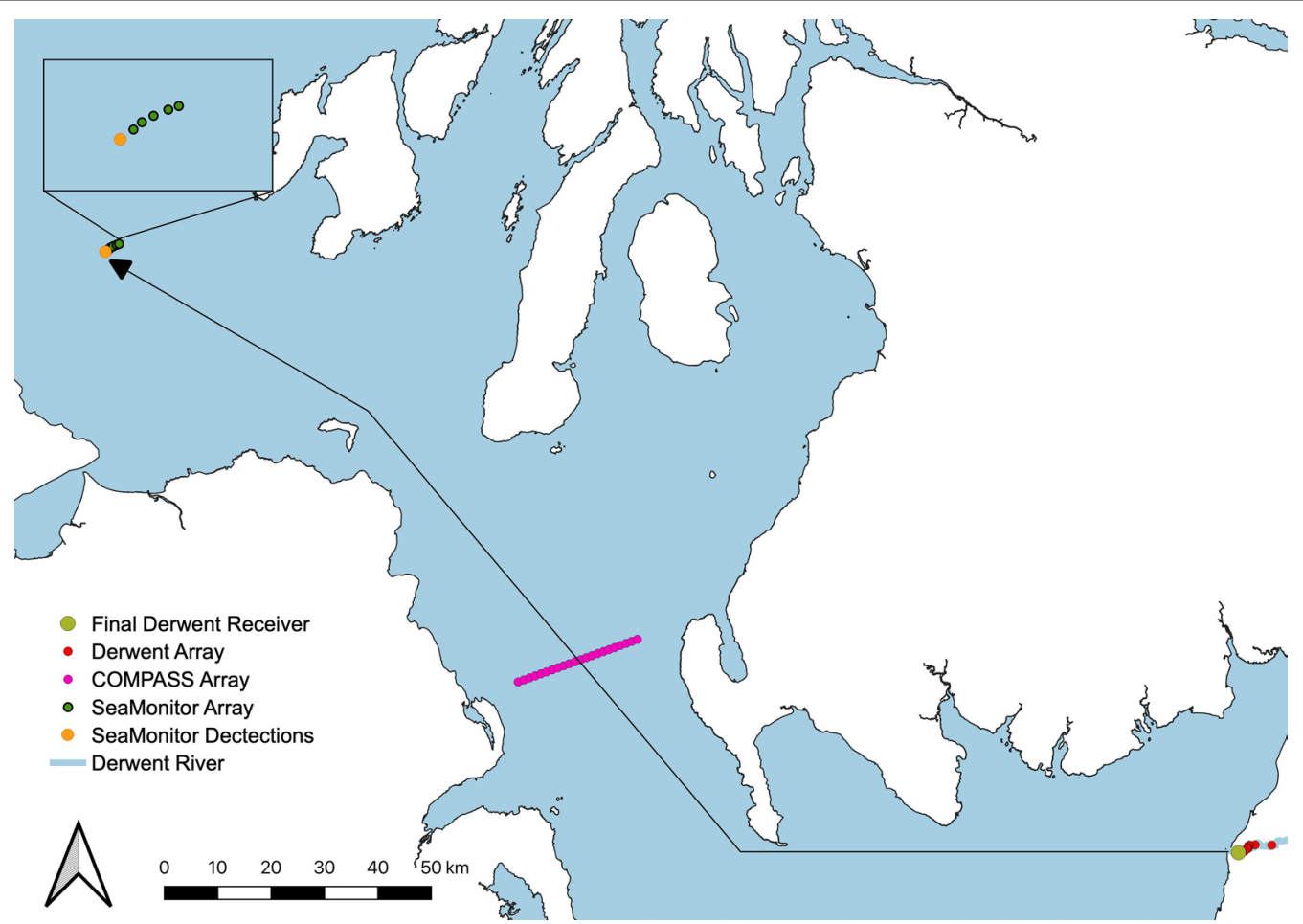

Fig. 5 Minimum theoretical distance travelled by fish 34,920, successfully migrating from the River Derwent's last river receiver to the sites of marine detection on both the COMPASS and SeaMonitor arrays in the Irish Sea

smolts in northern Scotland, concluded that post-smolts moved northwards along with the shelf edge currents [27]. Previous modelling by Mork et al. [11] indicated that the empirical data from the study by SALSEA-Merge [7] is to be consistent with fish following water currents and actively swimming in the direction of those currents. Dabrowski, et al. [24] analysed seasonal circulation and flushing of the Irish Sea and found that net flow through the Irish Sea varied significantly throughout the year, but that annually average flow $\left(2.50 \mathrm{~km}^{3} / \mathrm{d}\right)$ was northward, though southward flows were possible under certain meteorological conditions. The results of the study presented here and those of Barry et al. [4] imply that sea migrating post-smolts may well be navigating with the predominant current in this area, however, these movements may well be considerably more complex and much more detailed study is required. In contrast however, Newton et al. [23] used particle tracking to show that post-smolt Atlantic salmon were actively migrating in a direction that was not following the prevailing currents. The importance of using marine currents by migrating post-smolt Atlantic salmon thus requires further investigation.

Alternative possibilities for migratory pathway choice in post-smolts in marine environments could include that: (i) post-smolts disperse in random directions once the open coast is reached, (ii) post-smolts take the most direct migratory pathway to reach their feeding grounds in the northern hemisphere, (iii) post-smolts use coastlines as geographical markers during their migration to their northerly destination. None of the three alternative scenarios here can be resolved from the study presented here without marine current data, a higher receiver density of detections from more receivers located throughout the Irish Sea. For example, marine array in the southern Irish Sea would also be required to test if some fish exhibit a southerly migration trajectory or that there is random direction dispersal removing all assumptions that only a northern migration trajectory is chosen. Additionally, greater receiver density along the coastline and on existing marine arrays would be required to analyse if post-smolts are using coastlines as geographic markers for initial marine migration. This would provide increased detection efficiency and lead to greater accurate analysis and future understanding of post smolt migrating behaviour.

Receiver detections not only provide timestamps for individual migration trajectories but may also indicate if predation of a tagged fish has occurred. Based on the detections in this study, we have presumed that all River Derwent fish detected on the marine receivers were post-smolt Atlantic salmon and not a tag retained 
by a predator. Although this scenario cannot be completely ruled out, the assumption that detections are those of live post-smolts is supported by the similarity of the swimming speeds of detected smolts in this study, compared to other similar studies of Barry et al. [4] and Chaput et al. [15].

Currently literature on the coastal migration pathways of Atlantic salmon smolts is considerably limited. What information does exist particularly that from telemetry technology, is important to inform management strategy $[4,16,28]$ and could be used in conjunction with behavioural studies on current use and environmental pressures. Thus, this information can contribute to assessing overlap with potential threats, such as pelagic fisheries, and inform modelling, which can in turn predict future migration routes of a population during this important life stage. The findings from this study have also provided, along with the results from Barry et al. [4], insight into future receiver array placements within the region, enabling future research on smolt migration pathways within the Irish Sea.

\section{Conclusion}

This paper provides the first empirical evidence that west coast England Atlantic salmon smolts, adapting to the new marine environment, utilise the broad existing hydrodynamic conditions and display a northern migration trajectory in the Irish Sea, up to $262 \mathrm{~km}$ away from their natal river. Future work into understanding Irish Sea migration salmon pathways will require tracking a greater number of successful migrating individuals from rivers in both the east and west of the Irish Sea and a southern marine array is required to test for the potential of southern migration routes.

Gathering the results of this study has only been possible through cross jurisdictional and between research group collaboration. Meaningful and successful long distance migration telemetry studies are only possible when such collaborations are in place. The results of this study only emerged through the collaboration of three distinct jurisdictions and three separate research programmes: The Environment Agency/Natural England/University of Glasgow's River Derwent Tracking Project and the EU INTERREG VA funded COMPASS and SeaMonitor projects. Data sharing between projects has allowed a much greater insight into the northern migration of Atlantic salmon smolts through the Irish Sea from a river on the west coast of England. Further collaboration by the research community in this field is required to ensure marine migration trajectories are explored further.

\section{Authors' contributions}

This study was planned by RR, PR, BS, MF, HMH, SW, CEA and AG; executed by $A G, H M H, C E A, D D, R K, N O M, J B, F W$ and PK. All authors have contributed intellectually and to the writing of this manuscript. All authors have read and approved the final manuscript.

\section{Funding}

The main Funding bodies for this project were the Environment Agency, Cumbria and Natural England, Cumbria. Additional funding was provided by The Derwent Owners Association and Bowland Game: Isel Fishings.

\section{Availability of data and materials}

The datasets generated and/or analysed during the current study are available on reasonable request from Amy Green, Scottish Centre for Ecology and the Natural Environment, Glasgow, G63 0AW, UK.

\section{Declarations}

Ethics approval and consent to participate

All tagging was conducted under UK Home Office License Number PPL 70/8794.

\section{Consent for publication}

All authors have given their consent to the final manuscript being published.

\section{Competing interests}

The authors declare that they have no competing interests.

\section{Author details}

${ }^{1}$ Scottish Centre for Ecology and the Natural Environment, Glasgow G63 0AW, UK. ${ }^{2}$ Environment Agency, Ghyll Mount, Business Park, Irish Sea CA11 9BP, UK. ${ }^{3}$ Loughs Agency, 22 Victoria Rd, Irish Sea BT47 2AB, UK. ${ }^{4}$ Natural England, Ghyll Mount, Business Park, Penrith CA11 9BP, UK. ${ }^{5}$ Agri-Food and Biosciences Institute, 18a Newforge Lane, Belfast BT9 5PX, UK. ${ }^{6}$ The Marine Institute, Rinville West, Rinville, County Galway H91 R673, Ireland. 'Inland Fisheries Ireland, 3044 Lake Drive, Cheeverstown, Dublin, Ireland. ${ }^{8}$ Ocean Tracking Network, 6299 South St, Halifax, NS B3H 4R2, Canada. ${ }^{9}$ College of Biological Sciences, University of California, One Shields Avenue, Irish Sea, CA 95616, USA.

Received: 6 August 2021 Accepted: 10 January 2022

Published online: 26 January 2022

\section{References}

1. Klemetsen A, Amundsen PA, Dempson JB, Jonsson B, Jonsson N, O'connell MF, Mortensen E. Atlantic salmon Salmo salar L., brown trout Salmo trutta L. and Arctic charr Salvelinus alpinus (L.): a review of aspects of their life histories. Ecol Freshw Fish. 2003;12(1):1-59.

2. Armstrong JD, McKelvey S, Smith GW, Rycroft P, Fryer RJ. Effects of individual variation in length, condition and run-time on return rates of wildreared Atlantic salmon Salmo salar smolts. J Fish Biol. 2018;92(3):569-78.

3. Thorstad EB, Whoriskey F, Uglem I, Moore A, Rikardsen AH, Finstad B. A critical life stage of the Atlantic salmon Salmo salar: behaviour and survival during the smolt and initial post-smolt migration. J Fish Biol. 2012;81(2):500-42.

4. Barry J, Kennedy RJ, Rosell R, Roche WK. Atlantic salmon smolts in the Irish Sea: first evidence of a northerly migration trajectory. Fish Manag Ecol. 2020;27(5):517-22.

5. Flávio H, Kennedy R, Ensing D, Jepsen N, Aarestrup K. Marine mortality in the river? Atlantic salmon smolts under high predation pressure in the last kilometres of a river monitored for stock assessment. Fish Manag Ecol. 2020;27(1):92-101.

6. Riley WD, Ibbotson AT, Maxwell DL, Davison PI, Beaumont WR, Ives MJ. Development of schooling behaviour during the downstream migration of Atlantic salmon Salmo salar smolts in a chalk stream. J Fish Biol. 2014;85(4):1042-59. 
7. SALSEA-MERGE. Advancing understanding of Atlantic Salmon at Sea: merging genetics and ecology to resolve stock-specific migration and distribution patterns. Bergen: Institute of Marine Research. https://salmo natsea.com/wp-content/uploads/2020/09/Completed-Final-Report-SALSEA-Merge.pdf. 2012. Accessed 5 Nov 2021.

8. CEFAS, Environment Agency, Natural Resources Wales. Assessment of salmon stocks and fisheries in England and Wales. Gov.uk. https://assets. publishing.service.gov.uk/government/uploads/system/uploads/attac hment_data/file/919701/SalmonReport-2018-background_final.pdf. 2019. Accessed 5 Nov 2021.

9. Ahlbeck-Bergendahl I, April J, Bardarson H, Bolstad G, Bradbury I, Buoro M, et al. Working group on North Atlantic salmon (WGNAS). Denmark: ICES; 2019. p. 368.

10. Went AE. Movements of salmon Salmo salar (L.) to and from Irish waters. J Fish Biol. 1973;5(6):659-71

11. Mork KA, Gilbey J, Hansen LP, Jensen AJ, Jacobsen JA, Holm M, Holst JC, Maoiléidigh NÓ, Vikebø F, McGinnity P, Melle W. Modelling the migration of post-smolt Atlantic salmon (Salmo salar) in the Northeast Atlantic. ICES J Mar Sci. 2012;69(9):1616-24.

12. Klimley AP, MacFarlane RB, Sandstrom PT, Lindley ST. A summary of the use of electronic tagging to provide insights into salmon migration and survival. Environ Biol Fishes. 2013;96(2):419-28.

13. Lothian AJ, Newton M, Barry J, Walters M, Miller RC, Adams CE. Migration pathways, speed and mortality of Atlantic salmon (Salmo salar) smolts in a Scottish river and the near-shore coastal marine environment. Ecol Freshw Fish. 2018;27(2):549-58.

14. Newton M, Dodd JA, Barry J, Boylan P, Adams CE. The impact of a smallscale riverine obstacle on the upstream migration of Atlantic Salmon. Hydrobiologia. 2018;806(1):251-64.

15. Chaput G, Carr J, Daniels J, Tinker S, Jonsen I, Whoriskey F. Atlantic salmon (Salmo salar) smolt and early post-smolt migration and survival inferred from multi-year and multi-stock acoustic telemetry studies in the Gulf of St. Lawrence, northwest Atlantic. ICES J Mar Sci. 2019;76(4):1107-21.

16. Ounsley JP, Gallego A, Morris DJ, Armstrong JD. Regional variation in directed swimming by Atlantic salmon smolts leaving Scottish waters for their oceanic feeding grounds - a modelling study. ICES J Mar Sci. 2020;77(1):315-25.

17. Heupel MR, Simpfendorfer CA, Fitzpatrick R. Large-scale movement and reef fidelity of grey reef sharks. PloS ONE. 2010;5(3):e9650

18. Hitt S, Pittman SJ, Nemeth RS. Diel movements of fishes linked to benthic seascape structure in a Caribbean coral reef ecosystem. Mar Ecol Prog Ser. 2011;12(427):275-91.

19. Rowell TJ, Nemeth RS, Schärer MT, Appeldoorn RS. Fish sound production and acoustic telemetry reveal behaviors and spatial patterns associated with spawning aggregations of two Caribbean groupers. Mar Ecol Prog Ser. 2015;7(518):239-54.

20. Dunbar MJ, Thomson DH. West Greenland salmon and climatic change (Atlantic salmon, Salmo salar L.). Denmark: Meddelelser om Groenland; 1979.

21. Goulette GS, Hawkes JP, Kocik JF, Manning JP, Music PA, Wallinga JP, Zydlewski GB. Opportunistic acoustic telemetry platforms: benefits of collaboration in the Gulf of Maine. Fisheries. 2014;39(10):441-50.

22. Gazit T, Apostle R, Branton R. Deployment, tracking, and data management: technology and science for a global ocean tracking network. J Int Wildl Law Policy. 2013;16(2-3):112-27.

23. Newton M, Barry J, Lothian A, Main R, Honkanen H, Mckelvey S, Thompson P, Davies I, Brockie N, Stephen A, Murray RO. Counterintuitive active directional swimming behaviour by Atlantic salmon during seaward migration in the coastal zone. ICES J Mar Sci. 2021. https://doi.org/10. 1093/icesjms/fsab024.

24. Dabrowski T, Hartnett M, Olbert Al. Influence of seasonal circulation on flushing of the Irish Sea. Mar Pollut Bull. 2010;60(5):748-58.

25. Gaffney P. Use of satellite imagery to assess trends in water clarity in the Irish Sea (Ph.D.). Galway: National University of Ireland Galway; 2001.

26. Howarth M. SEA6 technical report. https://assets.publishing.service.gov. uk/government/uploads/system/uploads/attachment_data/file/197294/ SEA6_Hydrography_POL.pdf. 2015. Accessed 5 Nov 2021.

27. Shelton RG, Turrell WR, Macdonald A, McLaren IS, Nicoll NT. Records of post-smolt Atlantic salmon, Salmo salar L., in the Faroe-Shetland Channel in June 1996. Fish Res. 1997;31(1-2):159-62.
28. Ohashi K, Sheng J. Study of Atlantic salmon post-smolt movement in the Gulf of St. Lawrence using an individual-based model. Reg Stud Mar Sci. 2018:24:113-32.

\section{Publisher's Note}

Springer Nature remains neutral with regard to jurisdictional claims in published maps and institutional affiliations.
Ready to submit your research? Choose BMC and benefit from:

- fast, convenient online submission

- thorough peer review by experienced researchers in your field

- rapid publication on acceptance

- support for research data, including large and complex data types

- gold Open Access which fosters wider collaboration and increased citations

- maximum visibility for your research: over $100 \mathrm{M}$ website views per year

At BMC, research is always in progress.

Learn more biomedcentral.com/submissions 